\title{
THE POWHATAN CONFEDERACY, PAST AND PRESENT
}

\section{BY JAMES MOONEY}

In our study of Virginia Indian history, two facts must be borne in mind - first, the Indians under the jurisdiction of Powhatan and his successors constituted but one of several tribal groups within the limits of the future state, and occupied only a proportionate share of its territory; and second, the Jamestown colonists of 1607 were not the first whites with whom the natives came in contact, or even the earliest to attempt a settlement.

Whether or not Sebastian Cabot, in 1498 , had coasted so far south as Virginia, it is certain that Verazzano, in 1524 , and Gomez a year later, landed in the neighborhood of Chesapeake bay, the latter taking formal possession for the King of Spain. Throughout the remainder of the 16 th century the Virginia coast was frequently raided by Spanish slave hunters from the West Indies, and in 1570 the Jesuit Father Segura, with seven other priests and a number of lay companions, established a mission, which, after a brief existence, was destroyed by the natives, the whole company being massacred excepting one Indian boy. The massacre was revenged by Menendez some time afterward. Raleigh's abortive attempts at settlement on Roanoke island in $1584-87$ were outside the boundaries of Virginia, but the unfortunate result must have been known and discussed among all the tribes of the Chesapeake region. Strachey (ca. 1616) even claims that Powhatan himself was responsible for the destruction of the colony. The Jamestown colonists landed among a people who already knew and hated the whites.

The present state of Virginia has an area of 42,627 square miles, of which the tribes of the Powhatan confederacy held somewhat more than 8,000 , or about one-fifth of the whole, being the eastern tidewater section together with the two counties on the Eastern shore. Their western boundary was about the geologic break line marked by the falls of the principal rivers at Great Falls 
on the Potomac, Fredericksburg on the Rappahannock, Richmond on the James, and Petersburg on the Appomattox, and thence following the Blackwater divide by Suffolk to the coast. Strachey, indeed, if not also Smith, ${ }^{1}$ makes Powhatan's dominion extend to the head of Chesapeake bay, but there is abundant evidence in the early records that the Maryland tribes were enemies to those of Virginia, and held themselves independent. Those on the eastern shore of Virginia also seem to have been practically independent, as might have been inferred from the wide interval of water by which they were separated from the others; but as they spoke the Powhatan language and were within the Virginia jurisdiction, we may consider them with the Powhatan confederacy.

The twenty-eight Powhatan tribes enumerated in detail by Smith as existing in 1607,2 numbered, according to his estimate, about 2,385 fighting men; but as he omits from this count the people of Warraskoyac and of several other "king's houses" or tribal capitals indicated on his map, we are probably justified in making it a round 2,500 . Strachey, writing about 1616 , makes it 3,320 , but some of his figures are plainly too high. ${ }^{3}$ Taking the lower estimate we should have, on a reasonable calculation, a total population for the confederacy of about 8,500 , or about one inhabitant to the square mile. The same territory has now a population of considerably more than half a million. By way of comparison it may be stated that the Tuscarora, the leading tribe of eastern North Carolina, were estimated a century later at I,200 fighting men in

1 Strachey, History of Trauaile into Virginia, Hakluyt Society ed., 48, 1849. Smith (Arber ed., 35 r, I 884) states that the people of Accomack and Acohanock were subject to Powhatan. It is not clear from the wording of the paragraph whether or not he means to include any of the Maryland tribes in the same statement, but on the preceding page he says that the Sasquesahanocks (Conestoga) at the head of the bay were scarcely known to Powhatan. His map extends the name "Powhatan" into lower Maryland. The Powhatan were Algonquian, the Conestoga were Iroquoian.

2 Smith, Gen. Hist. Va. (1624), Arber ed., 347-8, 1884. In Smith's History, in the 1612 edition (Arber ed., 9I-55), he includes the "Warraskoyacks" at 40 fighting men, but puts the Payankatanke at 40 , the Patawomeke at 160 , and the Chickahamania at " neere 200 " fighting men. By the treaty with the Chickahamania in I6I4 (Smith, Virginia, Arber ed., 515), they agreed to be ready at any time to furnish 300 fighting men to the aid of the English. This agrees with Strachey's estimate about the same period.

3 Strachey, Virginiu, Hakluyt Society ed., 56-62, I 849 . 
fifteen towns (Lawson), while the powerful Iroquois confederates of New York were estimated in 1689 at I 2,850 souls.

Back of the Powhatan were other tribes of alien lineage and hostile to the tidewater people. On the upper Rappahannock were the confederated Mannahoac, and on the upper James the confederated Monacan, both apparently of Siouan stock and of ruder culture than the Powhatan. Southwest were the Nottoway and Meherrin of Iroquoian stock, on the rivers of those names, and on intimate terms with the kindred Tuscarora of North Carolina. Farther toward the southwest, on the upper waters of the Roanoke, were the Occaneechi, probably also of Siouan stock. Beyond them in the mountains about upper New river were the Mohetan, or Moketan, for whom we seem to have but a single authority, of date $1671 .{ }^{\prime}$ The Richahecrian, or Rickohockan, who came down from the mountains in 1656 and made bloody invasion of the lowlands, ${ }^{2}$ appear to be identical with the Cherokee, and can not fairly be considered a Virginia people.

As it was nearly a century after the founding of Jamestown before the white settlements extended beyond tidewater, we hear but little of these inland tribes until they were already far advanced toward ultimate extinction through wars, disease, and invasion by the dispossessed tribes. It is therefore impossible to form any definite calculation of their original population. We know that the Nottoway were a strong and influential tribe in the first settlement period, that in 1669 , by official-census, they largely outnumbered the principal Powhatan tribes, and that they retained their name and language as late as I 820 . The Meherrin, by the same census of 1669, were then equal in number to the Pamunkey - originally the strongest tribe of the Powhatan confederacy. We know that the principal Monacan town, above Richmond, was still an important Indian center in 1670 , and that the language of the Occaneechi was at one time the trade language over a large area. The Mannahoac, being wandering hunters for the greater part, were probably not numerous. As the fertile Shenandoah valley remained unknown

${ }^{1}$ Batts Exploration, 1671, in N.Y. Col. Docs., 111, 194-97, 1853; see also Bushnell, in this number, especially pp. $5 \mathbf{I}-52$.

2 Neill, Virginia Carolorum, 245, 327, 1886. 
until about $\mathrm{I} 720$, there is no record of its earlier history; but we can hardly believe that it was without Indian occupancy.

Making due allowance for the difference between mountain and lowland, and between hunting and agricultural or fishing habit, it seems reasonable to assume for these inland tribal groups - Mannahoac, Monacan, Nottoway, Meherrin, Occaneechi, and Mohetan - holding altogether four-fifths of the area of Virginia, a total original population at least equal to that of the single tribal group concentrated in the remaining one-fifth or tidewater section. This would give some 17,000 Indians as a conservative estimate for the whole state. The present population for the same area is, in round numbers, 2,000,000. ${ }^{1}$

This aboriginal population is now entirely extinct, with the exception of the 700 mixed-bloods of Powhatan stock. The Nottoway died where they had always lived, their last notice in history being in I 820 , when they numbered but 27 , all told, of whom only three spoke their own language. ${ }^{2}$ It is possible that some negroes of Southampton county may properly claim a strain of Nottoway blood. The Meherrin faded out at an earlier period. The other inland tribes, after having been driven south by the conquering Iroquois and back again by the Carolina settlers, until completely broken, were finally gathered by Governor Spotswood, about i 7 I 2 , at Fort Christanna, near the present Lawrenceville, in Brunswick county. They numbered then altogether less than $\mathrm{I}, 000$ souls. The Tuscarora war, the continued attacks of the Iroquois, and the aggressions of the whites, with their own acquired vices, hastened their decline until, about the year 1740, under the names of Saponi and Tutelo, the few survivors removed to the north and placed themselves under the protection of their old enemies, the Iroquois. The last full-blood died on the Grand River reserve, Ontario, in $187 \mathrm{I}^{3}$

To return now to the Powhatan. Following Jefferson, it is commonly said that their confederacy consisted of 30 tribes.

1 The census of 1900 gives $1,854,184$.

2 Morse, Report on Indian Affairs, 31, 1822 .

${ }^{3}$ For detailed account of these inland tribes see Mooney, Simuan Tribes of the East, Bulletin 22, Bureau of American Ethnology, I 894. 
This is approximate, but not exact. Smith (1607), our first and principal authority, names 28 tribes, giving the fighting strength of each, in his text, but indicates on his map 36 " king's houses," or tribal capitals. The whole number of villages, large and small, within the territory of the confederacy, as shown on the map, is 161 . A manuscript authority of 1622 ' says that the confederacy comprised " 32 Kingdomes." Strachey, about 1616 , gives a list of 32 chief jurisdictions, of which only. about half are identifiable with those of Smith's list. He assigns, however, two chiefs to the Appamattock, four to the Nandsamund, and three to the Pamunkey, thus reducing the number of distinct tribes to 26 . The census of 1669 , by which time the natives had been wasted by more than half a century of almost constant warfare, has the names of only i I of the Powhatan tribes noted by Smith, together with five others apparently resulting from shifting and new combinations of the broken remnants. In 1705 , according to Beverley, there remained only six settlements in existence on the mainland and nine on the Eastern shore, besides a few scattered individuals, the whole numbering together some 350 men, or perhaps $I, I 70$ in all. Thus within a single century the formidable Powhatan confederacy had wasted to about one-seventh of its original strength.

This result had been brought about by three Indian wars - in 1622, I644, and 1675 - together with constant killings and destructions on a smaller scale; by a system of clearances and man hunts inaugurated in 1644 and continued for some years; by smallpox and other epidemics; and by the general demoralization resulting from subjection to the conquering race.

Following is the statement of the Powhatan population, in fighting men, for the first century of colonization, as given by Smith in $1607,{ }^{2}$ Strachey about $1616,{ }^{3}$ the Virginia census of $1669,{ }^{*}$ and Beverley in $1705 .{ }^{5}$ The discrepancy in the names of the various lists is probably due to the progressive combination of broken tribes

'See Mr Bushnell's article in this number, p. 32.

${ }^{2}$ Smith, Virginia, Arber ed., 347-351, 1885.

${ }^{3}$ Strachey, Virginia, Hakluyt Society ed., 56-62, 1849 .

4 Neill, Virginia Carolorum, 325-326, 1886.

${ }^{5}$ Beverley, Virginia, book 111, 62-63, 1705. 
under new names, the abandonment of old sites, and the occupancy of new villages.

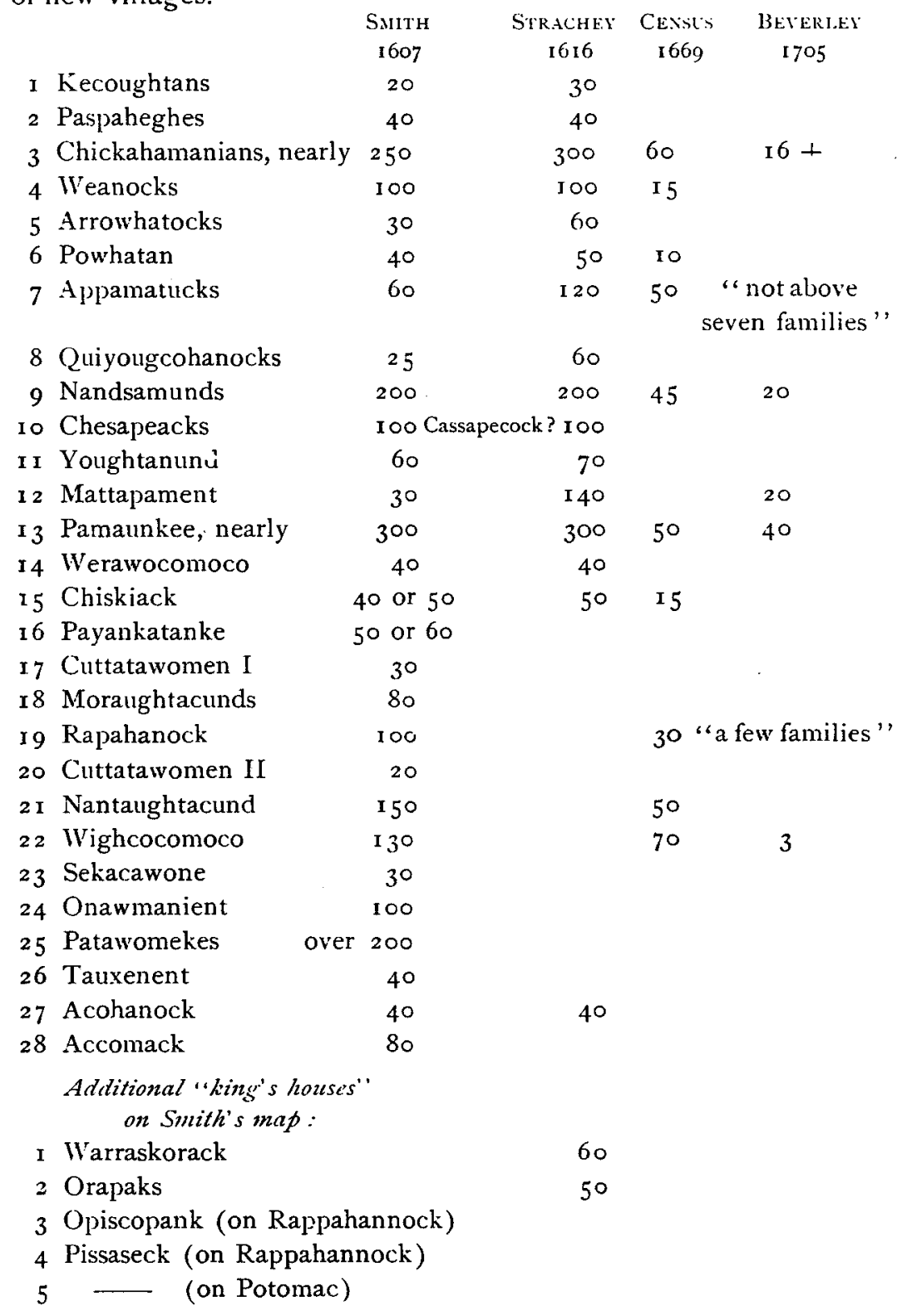


6 Uttamussak From Smith and Strachey references it appears that 7 Menapuciunt these were the three principal settlements of the 8 Kupkipcock Pamunkey, No. I3

Besides the 18 mames in Strachey's list which are identifiable with names on Smith's list or map, Strachey has also the following: Cantaunkack, 100 men; Mummapacune, I 00 men; Pataunck, I 00 men ; Kaposecocke, 400 men ; Pamareke, 400 men; Shamapa, Ioo men; Chepecho, 300 men ; Paraconos, Io men-a total of 26 tribal jurisdictions, estimated by Strachey to comprise 3,320 fighting men.

In addition to the I I names in the census of 1669 which are identifiable with Smith's list, the same census has also the following: Powchyicks, 30 bowmen; Totas-Chees, 40 bowmen; Portobaccoes, 6o bowmen; Mattehatique (included with Nanzcattico, alias Nantaughtacund); Appomatux (Westmoreland county and distinct from the tribe on the river of that name), Io bowmen - a total of 16 tribal communities with 605 fighting men, exclusive of the Eastern shore, which is not noted.

Beverley gives definite figures only for the two or three principal remnant tribes, but says that all the Indians of Virginia together could not then raise 500 fighting men, including the Nottoway and Meherrin, whom he puts at about I 30 . This might leave about 350 for the Powhatan tribes, including those on the Eastern shore, or from I, I 50 to I,200 souls. The remnants of the Siouan tribes already noted had not yet been gathered at Fort Christanna, but were at that time shifting about in central Carolina.

When the English landed at Jamestown in 1607, the Powhatan confederacy was a thing of recent origin. According to Smith's statement, which is borne out by Strachey, Powhatan, who was probably not yet sixty years of age at that time, had inherited only the territories of Powhatan, Arrowhatock, Appamatuck, Pamaunkee, Youghtanund, and Mattapament, all the other tribes and territories being reported as his own conquests. ${ }^{1}$ The six original tribes occupied the territory extending some 25 miles around Richmond, and comprised some 520 , or about one-fifth of the approximate 2,500

\footnotetext{
'Smith, Virginia, Arber ed., 375; Strachey, Virginia, 49. On page 347 Smith includes also Werawocomoco and Chiskiack.
} 
fighting men under his jurisdiction at the settlement period. Of these, the Pamunkey outnumbered all the other five together, and appear to have been the original nucleus of the confederacy, which probably had its beginning about the same period which Hewitt assigns for the formation of the Iroquois league, viz, 1570. The essential difference between the two was that, whereas the Iroquois league was founded upon mutual accommodation and common interest, the Powhatan confederacy was founded on conquest and despotic personal authority, and consequently fell to pieces with the death of the master, while the Iroquois league still exists with much of the old-time form.

As an example of Powhatan's methods, we are told how, in 1608 , for some infraction of his authority, he made a night attack on the Piankatank tribe, slaughtered all the men who could not escape, and carried off the women as captives. ${ }^{1} \quad$ Some years before he had taken advantage of the death of the chief of the Kecoughtan to invade their territory, kill all who made resistance, and transport the rest bodily to his own country, finally settling them at Piankatank, which he had previously depopulated. ${ }^{2}$ In the same way, on the strength of an ominous prophecy, he had exterminated the entire Chesapeak tribe and transplanted a colony of his own people in the desolated territory. ${ }^{3}$ To make his position more secure, he placed his sons or brothers as chiefs in several principal towns, while he himself ruled in his own capital. ${ }^{*}$ From all accounts, he was greatly feared and implicitly obeyed, governing rather by his own personality than according to tribal custom. The powerful Chickahominy, however, although accepting him as over-lord maintained their own home rule, and took an early opportunity to put themselves under the protection of the English. ${ }^{5}$

The displacement of the native tribes began almost with the finishing of the first stockade. The English, being ill supplied with provisions and not yet in position to procure more by their own

${ }^{1}$ Smith, Virginia, Arber ed., 378, 1885 ; Strachey, Virrinia, 36.

${ }^{2}$ Strachey, Virginia, 36, 6r.

3 Ibid., ror, 105.

1 See Strachey, 56-62.

strachey, 61 ; Smith, 51, 347, 515; Hamor, True Discourse of Virginia (1615), Albany ed., I I [1860]. 
labor, proceeded to live off the country, making constant demands which the helpless savages were not strong enough to resist. For instance, a foraging party was sent to Nandsamund to procure 400 bushels of corn that the Indians had promised in order to save their canoes, which the white men had seized and were coolly chopping to pieces. It was now winter, and the Indians pleaded that their corn was near spent - they had already loaded the first visitors with as much as the boats could carry - and that Powhatan had told them to keep the rest for themselves. So, "upon the discharging of our muskets they all fled and shot not an arrow. The first house we came to we set on fire, which when they perceived they desired we would make no more spoil and they would give us half they had. How they collected it I know not, but before night they loaded our three boats." Continuing, they visited one town after another, but found all the people fled until they reached Apamatuck, "where we found not much; that they had we equally divided," leaving the owners copper and other trinkets in payment.

On another occasion "we, having so much threatened their ruin and the razing of their houses, boats, and weirs," the frightened Indians promised, "though they wanted themselves, to fraught our ship and bring it aboard to avoid suspicion. So that, five or six days after, from all parts of the country within ten or twelve miles, in the extreme frost and snow, they brought us provision on their naked backs."

The result of it all was that before the colony was two years old the principal Indian settlements had been seized by the white men, Powhatan had withdrawn from his place within easy reach of Jamestown to a remote town on the head of Chickahominy river, and killings and burnings had become so frequent that no Englishman was safe alone outside the stockade of the fort.

Open war on a large scale was deferred, however, until 1622 , when Powhatan had been four years dead and his brother Opechancanough had succeeded to the Indian government. Pocahontas, for whose sake her father had restrained his own hostile feeling, had died before him. On March 22, 1622 (0. s.), Opechancanough began the war with a simultaneous and unexpected 
attack upon almost every settlement and plantation within the limits of the colony, by which 347 men, women, and children were massacred in the space of a few hours, most of them without the slightest chance for defending themselves, their lifeless bodies being mangled and abused in regular savage fashion. ${ }^{1}$ The Indians of the Fastern shore took no part in the massacre or the consequent war. The people of Potomac also remained friendly until driven to hostility by the massacre of a number of their people.

By this time, however, the colony had increased to nearly 4,000 , so that in spite of the number thus slaughtered - " there being yet, God be praised, eleven parts of twelve remaining " - there was no question of the outcome as soon as the settlers could organize for defence and retaliation. It is probable that the Powhatan confederates themselves were by this time reduced to a smaller number, even supposing that they could be held together to act as a unit.

Immediately on receipt of the news at home, orders were forwarded to the governor of the colony "to root out [the Indians] from being any longer a people. ... Wherefore, as they have merited, let them have a perpetual war without peace or truce, and, although they have desired it, without mercy, too." Exception was made, however, "for the preservation of the younger people of both sexes, whose bodies may by labor and service become profitable." Women were not included in this exception, but were doomed with the men. ${ }^{2}$ To accomplish the extermination, instructions were given to starve the Indians by burning and spoiling their corn fields, to hire the neighboring tribes to bring in their heads, and to organize and keep constantly in the field bands of armed men to "pursue and follow them, surprising them in their habitations, interrupting them in their hunting, burning their towns, demolishing their temples, destroying their canoes, plucking up their weirs, carrying away their corn, and depriving them of whatsoever may yield them succor or relief." Special rewards were promised

\footnotetext{
1 Smith, Arber ed., 572-583; Waterhouse, elc., in Neill, Iirginia Company of London, 317-346, 1869 .

2 Instructions from London Company, Aug. 1, 1622, in Neill, Virginia Company' of London, 331, 1869.
} 
for the seizure of any of the chiefs, with "a great and singular reward " to any one who could take Opechancanough. ${ }^{1}$

In January, 1623, the Virginia council reported to the home office that they had anticipated instructions by setting upon the Indians in all places, and that by computation and by the confession of the Indians themselves, "we have slain more of them this year than hath been slain before since the beginning of the colony." 2

By this war the Indians were so reduced in numbers and means that for more than twenty years there was doubtful truce, when Opechancanough determined upon a final effort, although now so old and feeble that he was no longer able to walk or even to open his eyes without help. As before, the rising began with sudden surprise and massacre, April I8, 1644 (o. s.), along the whole border, but with the heaviest attack along Pamunkey river, where the blind and decrepit but still unconquered chief commanded in person, carried about by his men from place to place. The number of whites killed in this second massacre is variously stated from 300 to 500 , the discrepancy being due to the fact that the colony was now so well advanced and the settlements spread out over so much territory that exact accounting was neither so easy nor of so much importance as in 1622 .

We have few details of this war, in which this time the advantage was so immensely on the side of the English that the result is summed up in the report of the Assembly in March, I646, that the Indians were then "so routed and dispersed that they are no longer a nation, and we now suffer only from robbery by a few starved outlaws." 3

The same Assembly authorized other expeditions and the buildof forts along the border. In the end, Opechancanough was taken and brought to Jamestown, where he was shot in prison by one of his guards. His successor, in October, 1646, made a treaty of submission by which the Indians agreed to abandon everything below the falls on James (Richmond) and Pamunkey (near Han-

1 Instructions from London Company, itid., 331-32.

2 Report of Governor and Council, Jan. 20, 1623, Neill, Virginia Company, 365, 1869. We modernize the spelling.

3 Neill, Virginia Carolorum, I9I, 1886. 
over ?) rivers, and to restrict themselves on the north to the territory between the York and the Rappahannock. ${ }^{1}$

In ${ }_{1654}$, on occasion of another Indian alarm, a large force was ordered against the Indians on Rappahannock river, but no details of the result are given. ${ }^{2}$ In the next year the Indian lands were made inalienable except by permission of the Assembly. ${ }^{3}$

In 1656 a large body of strange Indians, called Richahecrians (possibly Cherokee), came down from the mountains and made camp at the falls of James river, apparently to start a friendly acquaintance for trade purposes. A force of $100 \mathrm{men}$, however, under Col. Edward Hill, was sent to drive them back. Totopotomoi, chief of the Pamunkey, joined the expedition with 100 of his own men. The result was disastrous. The English were defeated, the Pamunkey chief and most of his men were killed, and Hill was obliged to make terms with the Richahecrians, for which he was afterward brought to trial by the Assembly.

In 1675 came another Indian war, involving Maryland as well as Virginia, and known in history as Bacon's Rebellion from the fact that the leader of the Virginia volunteers acted in direct opposition to the colonial governor, Berkeley. The immediate cause was a series of small raids upon the Virginia frontier by Indians from Maryland, either refugees fleeing before the Iroquois, or, according to Beverley, instigated to mischief by the jealousy of New York traders. ${ }^{5}$ A force of 1,000 men, including cavalry, was authorized against the Indians, and it was made death, with forfeiture of estate, to sell, directly or indirectly, powder or firearms to Indians. The tribes most concerned were the Susquehanna (Conestoga) and Doeg (Nanticoke?) of Maryland, with the Occaneechi and others of western Virginia. The broken Powhatan tribes,

1 For the war of 1644-46, see Beverley, History of Virginin, bk. I, 50-53, 17r5; Neill, Virginia Caroloram, 178-194, I886; Drake, Indians of N. Am., bk. Iv, 2122,1848 .

${ }^{2}$ Neill, Virginia Carolonum, 238, 1886.

${ }^{3}$ Ibid., 242.

4 Neill, Virginia Carolorum, 245, 1886; Burk, Virginia, Ir, 105, 1805; Drake, Indians of N. Am., bk. IV, 22, 1848; T. M., Bacon's Rebellion (1705), reprint in Force's Tracts, I, 1835 .

${ }^{5}$ Reverley, Virginia, bk. I, 69, 1705. 
under the woman chief, Queen Anne of Pamunkey, took no part in the hosti'ities, but suffered, as usual, in the result. In 1677 the war was brought to a close by a general treaty of peace with all the tribes in relation with the Virginia government, by which they submitted to the English authority and were confirmed in the possession of their tribal lands, subject each to an annual quitrent of three arrows and a tribute of beaver skins. At the same time they bound themselves to give immediate notice of the appearance of any strange Indians on the frontier, and to be ready to furnish a quota of men when required to serve against an enemy. The queen of Pamunkey, widow of Totopotomoi, already mentioned, was recognized in certain special dignities; The signatory tribes were the Pamunkey, Appamattoc, Weanoc, Nansemond, Nantaughtacund, and Portabaccos - all of the old Powhatan confederacy; with the Nottoway, Meherrin, Monacan, and Saponi. ${ }^{1}$

This treaty may be considered to mark the end of the Indian period. Henceforth the dwindling tribes appear chiefly as appealing for protection or justice, the chronic grievance being trespass upon their reserved lands. From various references it is evident that Indian slavery was common even after peace had come, and this probably hastened the process of intermixture with the negro race. Their last appearance in treaty negotiations was at Albany, in 1722 , when, through the efforts of the governors of New York, Pennsylvania, and Virginia, the Iroquois made definite promise to refrain from further inroads upon the Virginia tribes, among whom were named the Nansemond, Pamunkey, and Chickahominy, with the Nottoway, Meherrin, and Christanna Indians, under which last name were included the remnants of the Siouan tribes of the East. $^{2}$

According to Beverley's statement, as already noted, the whole

${ }^{1}$ Neill, Virginia Carolornm, 346-385, 1886; Beverley, Virginia, bk. I, 68, passim, 1705 ; Mooney, Siouan Tribes of the East, 54, 1894 ; Virginia Colonial Records, with treaty and bibliography of Bacon's Rebellion, in $V_{a t}$. Mag. of Hist and Biography', $\mathrm{xIV}$, no. 3, Richmond, Jan., I907. We have standardized the tribal spellings.

2 This seems to be the treaty meant by Jefferson (Notes on liigrinia, Boston ed., 131, 1802). There is no record in the Niow York Colonial Documints of any similar treaty in 1685 , as stated by him, but in 1682 a like arrangement was made at Albany in behalf of the Maryland Indians. 
Indian population within the explored portions of Virginia, numbered, in 1705 , fewer than 500 able men, of whom the Powhatan remnants may have had 350 . The combined white and negro population at the same period amounted to perhaps I00,000 souls. ${ }^{1}$ In 1723 the Nansemond petitioned Virginia for help, saying that North Carolina had surveyed their whole remaining lands, and that her citizens were building their houses upon the Indian corn fields. ${ }^{2}$ In I 699 the Accohanock Indians of the Eastern shore had made similar complaint that "the English have seated upon all the lands which were reserved to the Indians by the Articles of Peace" (1677), and that " the Indians not having any lands of their own "were in great poverty and necessity. ${ }^{3}$ In 1786 the Gingaskin Indians [Gangascoe, of Beverley], also of the Eastern shore and representing the old Accomac, in petition to the Virginia government stated that "it must be remembered on record that but a small pittance was allowed us of our wide-extended territories for our subsistence, and small as it is, we understand, by the application of some or one gentleman who claims it as his right, it is perhaps to be wrested from being possessed by your already much distressed and unhappy petitioners." " Always consistently the same story.

In his Notes on Virginia, written originally in 1781 , Jefferson has a paragraph on the condition of the Powhatan remnant at that time, which contains as many misstatements as could well be crowded into the same number of lines :

Very little can now be discovered of the subsequent history of these tribes severally. The Chickahominies removed, about the year $\mathrm{x} 66 \mathrm{I}$, to Mattapony River. Their chief, with one from each of the tribes of the Pamunkies and Mattaponies, attended the treaty of Albany in 1685 . This seems to have been the last chapter in their history. They retained, however, their separate name so late as 1705 , and were at length blended with the Pamunkies and Mattaponies, and exist at present only under their names. There remain of the Mattaponies three or four inen only, and they have more negro than Indian blood in them. They have lost their language, have reduced themselves, by voluntary sales, to about fifty

'See Jefferson's census of tithes, Notes on Virginia, Boston ed, I17, 1802.

2 Virginia State Papers, 1, 205, 1879.

3 [bid., 65.

4 Ibid., 214. The name is given as Lingaskin, by error of reading. 
acres of land, which lie on the river of their own name, and have from time to time been joining the Pamunkies, from whom they are distant but ro miles. The Pamunkies are reduced to about ro or I 2 men, tolerably pure from mixture with other colors. The older ones among them preserve their language in a small degree, which are the last vestiges on earth, as far as we know, of the Powhatan language. They have about 300 acres of very fertile land on Pamunkey River, so encompassed by water that a gate shuts in the whole. ${ }^{1}$

The grossest error in this paragraph is in regard to the Chickahominy. From a petition of I 689 it appears that they, or some of them, had temporarily joined the Pamunkey to escape the inroads of the Seneca (i. e., here, the Iroquois). This removal did not take place about I66I. We know from the census of 1669 that it must have been subsequent to the latter date, and it probably occurred in consequence of the invasion of northern tribes which brought about Bacon's Rebellion in 1675 . There is no record of any Virginia tribes attending at Albany in 1685, and the date should be 1722 - nearly forty years later. So far from the name being extinct, the tribe is still, as it probably was from the beginning, the largest of the confederacy. Both Mattapony and Pamunkey must have been much more numerous than represented, and with more speakers of the old language, while the Nansemond, and the considerable remnant still existing in 178I on the Eastern shore and in some of the tidewater "necks," are not noted at all. The main reserve contains 800 acres instead of 300 , as stated. ${ }^{2}$

In I 844 the Rev. E. A. Dalrymple collected a few words from the Pamunkey, which, however, with the single exception of the word for "one," nekkut (necut in Smith's Vocabulary), are open to grave suspicion. ${ }^{3}$ In 189 I $\operatorname{Dr}$ Albert S. Gatschet, of the Bureau of American Ethnology, made a short visit to them, and in 1894 $\mathrm{Mr}$ John G. Pollard published a brief bulletin describing their condition and form of government at that time. ${ }^{*}$

${ }^{1}$ Jefferson (178I), Notes on Virginia, Boston ed., 131, 1802 .

${ }^{2}$ In the same paragraph Jefferson states that the Nottoway were then reduced to a few women, not a male being left, although nearly forty years later, according to Morse's official report, there were still 27 on the reservation, several of whom spoke the language. Jefferson's identification of the Monacan as Tuscarora is also incorrect.

I In Historical Magazine, N. Y., Ist s., II, I82, 1858.

4he Pamunkey Indians of Virginia, Bulletin 17, Bur. Am. Ethnol., 1894. 
In I 889 the present writer had undertaken a study of the Indian history and tribal remains of the south Atlantic region from Delaware river to Savannah river. As a preliminary, $\mathrm{I}, 000$ circular letters, requesting information in regard to Indian local names, ancient remains, and survivors of pure or mixed Indian origin, were sent out over the region under consideration, resulting in the securing of considerable valuable information. This was followed up by correspondence and library investigation, some results of which were published in the American Anthropologist from time to time, together with a bulletin publication by the Bureau of American Ethnology in $1894 .^{2}$

Replies from the Eastern shore, where Beverley's statement might make 500 or 600 Indians, were to the effect that the few who remained at the beginning of the last century had become so mixed with negro blood that in the general alarm occasioned by the Nat Turner slave rising in 1831 they had been classed as full negroes and driven from their homes, so that their identity was lost. Later information tends to confirm this ; but, as there are still individuals among the Maryland negroes who claim strains of Nanticoke, Piscataway, and Wicocomoco blood, it is possible that others yet keep up the name of Gingaskin, or Accohannock. In this connection it is in place to state that there is undoubtedly a considerable infusion of Indian blood among the negroes of the whole south Atlantic tidewater region.

On the mainland, the circular replies and later correspondence indicated the existence of several bodies and scattered families of Indian descent, besides those having state recognition under the names of Pamunkey and Mattapony. Upon a theory which proved to be correct, it was assumed that the largest bodies of Indian admixture would still be found where the largest tribes had originally resided. Smith, in 1607 , estimated six Powhatan tribes as having each more than 100 warriors, viz: Pamunkey (300), Chickahominy (250), Potomac (over 200), Nansemond (200), Nantaughtacund ( 150 ), and Wicocomoco (I30). Of these the Pamunkey, Nansemond, Chickahominy, and Wicocomoco still kept the name in 1705 , and were reported at about 40,30, 16, and 3 bowmen, respectively,

\footnotetext{
1 The Siouan Tribes of the East, Bull. 22, Bur. Am. Ethnol., Washington, 1894 .
} 
besides four other small bodies. ${ }^{1}$ Following this clue, the country east of Richmond and south of Norfolk was visited in 1899 and again in I901, resulting in the discovery that not only the Pamunkey and Mattapony, but also the ancient Chickahominy and Nansemond, were still represented by several hundred mixed-bloods. Smaller groups of the same mixed pedigree were also heard of, but not visited.

In all of these bands the blood of three races is commingled, with the Indian blood sufficiently preponderating to give stamp to the physiognomy and hair characteristics. It is probable that from intermarriage nearly the same mixture is in all alike, although it does not show equally in the features. Thus, many would pass among strangers as ordinary negroes; a few show no trace of any but white blood; while a few families and individuals might pass as full-blood Indians in any western tribe. Notwithstanding the large percentage of negro blood, the Indian race feeling is strong. This is due largely, according to their own statement, to the fact that intermixture was frequently forced upon them in the old days, with the deliberate purpose of claiming their children for slavery. Their one great dread is that their wasted numbers may lose their identity by absorption in the black race, and against this they have struggled for a full century. As we have seen, it was this cause which led to the dispersal of the Eastern shore remnant in 1831 , and harsh measures were enforced upon the other Indians at the same time. In 1859 , under the alarm produced by the John Brown raid, they again fell under suspicion, and the Pamunkey, in spite of state recognition as Indians, were temporarily disarmed, while the unorganized bands were subjected to worse treatment. In the Civil war a number joined the Union service as soldiers, guides, or seamen, while some fled to Canada to avoid conscription in the Confederate service. Intermarriage with the negro race is now forbidden by Pamunkey law and frowned upon in the other bands. To prevent annoyance when traveling, under recent Virginia legislation, the Pamunkey now carry official certificates of tribal membership ; and for similar reasons the unorganized Chickahominy and Nansemond are now making strong effort for state recognition as Indian tribes, such as is accorded the Pamunkey and Mattapony and the so-called "Croatan Indians" of North Carolina.

\footnotetext{
'See Beverley's statement, already noted.

AM. ANTH., N. S., 9-ro.
} 
They have entirely lost their aboriginal language and customs, if we except their devotion to the water, and differ but little from their white neighbors. According to the statements of several persons of middle age, their parents some fifty years ago had conversational knowledge of the old language. Even this knowledge must have been limited, as the present writer, by the most careful search, could find but one old man, William W. Weaver, a Nansemond, from whom even half a dozen words could be obtained. $\mathrm{He}$ was then so feeble, mentally and physically, that he could not be questioned with any satisfaction. He died about a year later, in rgo2, and with him faded away the last echo of the Powhatan as a living language. From the distribution of the original tribes and their former jealousies, it is probable that the language had several well-marked dialects.

On account of the old man's condition, even the half-dozen words obtained from him needed confirmation by his son, then fiftythree years of age, who claimed to have remembered them from his father. They are given here for what they may be worth, with comparison from the Powhatan vocabularies of Smith and Strachey, and the cognate Pampticough of North Carolina, of Lawson:

$\begin{array}{lllll} & \text { Nansemond } & \text { Smith } & \text { Strachey } & \text { Pampticough (Lazuson) } \\ \text { One } & \text { nikătwin } & \text { necut } & \text { nekut } & \text { weembot } \\ \text { Two } & \text { näkătwìn } & \text { ningh } & \text { ninge } & \text { neshinnauh } \\ \text { Three } & \text { nikwásăti } & \text { nuss } & \text { nousough } & \text { nish-wonner } \\ \text { Four } & \text { toisiăw' } & \text { yowgh } & \text { yeough } & \text { yau-ooner } \\ \text { Five } & \text { misshä'naw } & \text { paranske } & & \text { umperren } \\ \text { dog } & \text { marímo } & - & \text { attemous } & \end{array}$

The appended census of the four principal bands, in IgOI, was compiled from information furnished in conference by the principal men of each band, and may therefore be considered as an official statement of their membership as recognized by themselves. The figures are probably nearly the same today.

Practically all of them can read and write. All are consistent members of the Baptist Church, maintaining their own church and school organizations; they are self-supporting, industrious, lawabiding, and hospitable, with no paupers or criminals, and constitute in every way a worthy factor in the community. 


\section{The Pamunkey}

The Pamunkey are the remnant of the nucleus tribe of the old confederacy, and the lineal descendants of Powhatan and his successors. They have maintained their organization as a tribe under colonial and state government, and have kept up more of the Indian form and tradition than any of the others. They have a state reservation of some 800 acres, the same which Jefferson described in $178 \mathrm{I}$, in a bend of Pamunkey river, in King William county, Virginia, with postoffice and railroad station at White House, 24 miles eastward from Richmond. They derive their living almost entirely from the water, taking large quantities of herring and shad by seine, according to the season, with ducks, reedbirds, and an occasional sturgeon for disposal to Baltimore commission houses. Their fields of corn and beans are cultivated chiefly by hired negro labor. They neither vote nor pay taxes, but are governed by an elected chief and council, subject to the supervision of trustees appointed by the state. Deer and wild turkey are still found in their country, and, in continuance of the old colonial allegiance, they make an annual Thanksgiving present of game to the governor of the state. Their chief in I 900 was Theophilus Dennis, who has since been succeeded by George M. Cook, his brother-in-law. They number at home and abroad about I 50 souls.

According to the statement of former chief Terrill Bradby of the Pamunkey, aged sixty-six in 1899 , the numerous Bradbys of the Pamunkey and Chickahominy tribes all have descent from a white man, his great-grandfather, who, about the Revolutionary period, married a Chickahominy woman, by whom he had three sons, one of whom was Terrill's grandfather. ${ }^{1}$

Allmond, E. R. (Mattapony), $w$ and $6 \mathrm{c}$.

Bradby, Wm. 'Terrill (ex-chief), and $6 c$ and step-c; scattered.

BRADBY, Wm. S. ( $w$ white).

BradBY, Cruzetta, and $5 c$.

BradBY, Riley, and $2 c$.

BradBy, James E., $w$ and $2 c$.
BRAOBY, Roger, and $w$.

BradBy, Charles S. (ex-chief), wand $4 c$.

Bradby, Evans, $m$ and $3 c$.

Collins, Simeon, $w$ and $6 c$.

Collins, Ellen.

Collins, Emma J.

Collins, Union, $w$ and $4 c$.

1 Abbreviations : $m=$ mother ; $w=$ wife ; $h=$ husband ; $s=$ son ; $d=$ daughter ; $c=$ child or children ; $g r c=$ grandchildren ; $g r s=$ grandson $; b=$ brother $; s r=$ sister. 
Collins, John T., w and $4 c$.

Collins, Alfonzo (we Mattapony);

- Philadelphia.

Cook, Mindora.

Соoк, George M., $m, w$ and $5 c$.

Dennis, Theophilus (ex-chief), and $m$.

Dennis, John T.

DENNis, Thomas.

Dennis, Elizabeth (Philadelphia ?).

Hawkes, Delila ( $h$ alien mixedblood) ; Petersburg.

Holmes, Richard L., $w$ and $6 c$.

LANGSTON, John ( $w$ Mattapony), $w$ and $9 c$.

Langston, Lucy A., and $6 c$.

LANGSTON, Wm., and $w$.
LANGSTON, James H. (Richmond).

Miles, Rev. James P., and $3 c$.

Miles, Jacob ( $w$ white), and $5 c$.

Miles, Robert W., $w$ and $5 c$.

FAGE, A. J., $w$ and $I c$.

PAGE, Ellen.

PAGE, James E., and I $c$ (New York).

PAGE, Leroy (Newport News).

SAMPSON, Richard, and $1 \epsilon$ (New York).

SAMPSON, Sterling Y. ( $w$ white), and I $c$.

Swett, W. G., and $4 c$.

SweTt, George A. (w Mattapony), $w$ and $\mathbf{c} c$; Pinner's Point, Norfolk co. SwETr, Frank.

Others with Mormons in the West.

The Mattapony ${ }^{1}$

The present Mattapony are chiefly an offshoot from the $\mathrm{Pa}$ munkey. They have state recognition as a tribe, without citizenship or taxes, and have a small reservation of some 50 acres, with larger personal holdings, on the south bank of Mattapony river, King William county, about Io miles distant from White House. They live principally by lumbering and farming, and have no chief or council, but combine their affairs with the Pamunkey. They number about 40 souls.

Allmond, Thornton, $w$ and $3 c$.

Allmond, Caley, $m, 6 b$ and $s r$.

Allmond, Esten, and $1 c$; also married $d$ with $\mathbf{I} c$ in Philadelphia.

Collins, Abbie ( $h$ Pamunkey).

Costello, Norman, and $2 c$.

Costello, Epharis, $w$ and $5 c$.
Laxgston, Mary Eliza ( $/$ Pámunkey). MAJOR, Lee, $w$ and $3 c$.

Reid, Blanche ( $/$ white), and I $c$; in Texas.

Tuppins, Nannie, I $c$ and nephew (Baltimore?).

Tuppins, Alice.

\section{The Chickahominy}

The Chickahominy, although without regular organization or state recognition, are the largest of the existing bands, occupying individual holdings along both sides of the Chickahominy in Charles City and New Kent counties, besides about 20 persons in

1 Accented on first and last syllables: Mat'-ta-po-ny'. 
neighboring counties. A few Pamunkey reside with them, and both bands are much intermarried. They divide their time about equally between fishing and farming, according to the season. Within the last few years they are making an effort to effect a tribal organization, under the leadership of William $H$. Adkins. They number in all about 220 souls, of whom nearly three-fourths bear the family names of Adkins and Bradby.

Adkins, Wm. H., chief (Bradley's

Store P. O., Charles City co.), w, $m$, and $7 \mathrm{c}$.

ADKINs, Spotswood, $w$ and $8 c$.

ADKINs, James E., $w$ and $I I c$.

ADkins, Thomas Allen, $w$ and $5 c$.

Adkins, Thomas (senior), $w$ and $4 c$.

Adkins, Henry E., $w$ and $i \mathrm{I} c$.

Adkins, Allen, $w$ and $3 c$.

Adkins, Aurelius, $w$ and $2 c$.

Apkixs, William, $w$ and $7 c$.

ADkins, Prince Edward, $w$ and $\mathrm{I} c$.

Adkins, Tazewell, $w$ and $2 c$.

Adkins, Edward (Providence Forge

P. O., New Kent co.), $w$ and $9 c$.

Adkins, Robert, $w$ and $3 c$.

BradBY, Sanford (Bradley's Store P.

O., Charles City co.), w.

Bradby, John Williams, $w$ and $2 c$.

Bradby, Burrell, w (a Pamunkey) and $8 c$.

Bradby, John A., I $c$.

Bradby, Porterfield, $w$ and $3 c$.

BradBy, Allen.

BradBY, Henry Tazewell (Blair's Wharf P. O., Prince George co.); $w$ was a Canadian Indian, $6 c$.

BRADBY, . Bolen (Bolling ?), Fergusson's Wharf $P$. O., Isle of Wight co. ; $w$ white, I $s$.

BRADBY, Luella (mouth of Chickahominy, James City co.), $5 \mathrm{c}$.

Bradby, Maria J. (Providence Forge P. O., New Kent co.), $4 c$.

BRADBY, Alexander J. (Boulevard P. O., New Kent co.), $w$ and $6 c$.
Cotman, Robert (Roxbury P. O., Charles City co. ; some "foreign" Virginia tribe; grandfather white), $w$ and $3 c$.

Holmes, Elias (Newport News, Warwick co., from New Kent co.), w and $3 c$.

Holmes, Irene (Newport News), $2 \mathrm{sr}$. JEFFERSon, Thomas (Bradley's Store P. O., Charles City co.), $2 b$, I $s r$. Jefferson, Peter (Westover P. O., Charles City co.).

JefFerson, Sherman, $w$ and $2 c$.

JoNEs, John (Bradley's Store P. O.), $w$ and $5 \mathrm{c}$.

Miles, Graham (Bradley's Store P. O.), $w$ and $8 c$.

Miles, Graham B. (unmarried nephew of above), $2 b, 5 s r$.

Miles, Harold (a Pamunkey, Newport News), $w$.

Miles, Jesse (Westover P. O., Charles City co.).

Stuart, John, and $w$ (Providence Forge P. O., New Kent co.).

SWETT, John J., $w$, $m$, and I $c$.

THOMPSON, William (half-brother of Jesse Miles), Westover P. $O$.

Wynne, Ferdinand (a Pamunkey with Chickahominy $w$, Providence Forge, New Kent co.), $w$ and I I $c$.

Wynne, Winslow (Pamunkey, brother of Ferdinand Wynne, widower of Chickahominy $w$ ), I $d$ (adopted in Pamunkeys), $2 s$; Tunstall P. O., New Kent co. 
The NANSEMOND

The Nansemond have no state recognition or tribal organization, and reside chiefly in the country southwest from Portsmouth and Norfolk, in Norfolk county. They are all truck farmers, shipping their produce to Norfolk commission houses. Many also have served from time to time as sailors on coasting vessels. Although without any regular chief, their principal man is probably A. A. Bass, of Bowers Hill, Norfolk county. They number about I 80 souls. The comparatively large number of family names is due to the frequent intermarriage of children of the original stock, chiefly Bass and Weaver, with "whites" in Portsmouth and elsewhere. In consequence of this dispersion, those at home have lost trace of the names of some of the younger generation abroad, so that the whole number may fairly be placed at 200 of the mixed blood.

BASs, A. A. ( $w$ white), and $8 c$.

BAss, Jesse L. ( $b$ of above), $w$ white. BAss, Azriah ( $b$ of above), $m$ and $6 c$.

BAss, Winfield.

BAss, Paul, and $w$.

BASS, Eli N., and $\tau$.

Bass, James N. ( $w$ white), and $2 c$.

BAss, J. T. (z white).

BAss, Fred.

Bass, Josephine.

BAss, Iverson ( $b$ of A. A. Bass), $z^{\prime}$ white, and $3 c$.

Bateman, Cornelia ( $h$ white), $2 c$ and $3 \mathrm{grc}$. Some in Portsmouth.

BATEMAN, Charles ( $f$ white); Baltimore.

BATEMAN, Lewis ( $f$ white); Suffolk. BATEMAN, Hal ( $f$ white) ; Suffolk.

BISSELI, Edward ( $w$ white), $3 c$.

BISSELL, Walter ( $m$ white).

BISSELl, Mit ( $m$ white).

BoND, Ellen ( $h$ white), and $5 c ; 3$ others married to "whites".

BOND, 2 grs of Ellen Bond ( $m$ white). Bond, Lemwood, and $2 s$ ( $m$ white).
BкIGHT, Elizabeth ( $h$ white), and $4 c$.

BRIGHT, Louisa, and $5 c$.

BRIGHT, Harlan.

BrigkT, Eva, and $2 b$ ( $g r c$ of Elizabeth Bright, $m$ white).

Brady, Ella, and $1 c$ ( $h$ white).

CAPLE, Emma, and I $c$ ( $h$ white).

Collins, Kerry ( $w$ white); Portsmouth.

Collins, John, and $-c$; Baltimore.

Collins, "Bird", and $-c$; Baltimore.

Collins, Maggie, and $-c$; Baltimore.

Craigns, Mary ( $l$ white), and $3 c$; Savannah.

GAYLORD, Maggie ( $h$ white), and $3 c$. Gray, Harriet Ann ( $h$ white), and I $c$; Portsmouth.

Grees, Jurutha ( $/$ white); Portsmouth.

HARMON, Edward (white? his wife is a Weaver), zo and $5 c$; Portsmouth.

HARMox, Edward, Jr (grs of above); Portsmouth. 
Holloway, Missouri ( $h$ white), and Io $c$; Brambleton.

HOWARD, Sarah ( $h$ white), and $5 c$. Joses, Emma ( $f$ white).

OKAY, Maggie ( $h$ white), and $2 c$; Portsmouth.

OSBORN, Emma ( $h$ white).

Porter, Amanda ( $h$ white), and $3 c$.

Price, John ( $f$ and $w$ white), and $3 c$.

Price, George ( $f$ and $w$ white), and

$2 c$; Portsmouth.

Rowland, Fannie ( $h$ white), and $\mathrm{I} c$;

Portsmouth.

SAwYer, Emerson ( $w$ white), and 2 $c$; Brambleton.

SAwTer, Samuel ( $w$ white), and $5 c$;

Baltimore.

ScotT, Gertie (// white).
Sebastiax, Ann.

Simcoe, Mary ( $h$ white), and $2 c$.

Wealer, IV. WT. (last speaker of the language, died I902, aged 84), and $w$.

WEAYER, James E., $w$ and $4 c$.

IVEAVER, W. W. Jr; Portsmouth.

Wearer, Cornejus ( $w$ white), and 4 i; Philadelphia.

WeAver, Henrietta.

WEAYER, Lavinia, and $3 c$; Baltimore.

WHITE, Emma ( $h$ white), and $2 c$; Portsmouth.

White, Lovey Ann ( $/$ white), and 3 $c$; Portsmouth.

WiLkiss, Molly ( $k$ white).

Williams, Drusilla; Portsmouth.

\section{OTHER BANDS}

Besides the four larger bands, we have information orally and by correspondence of several other small groups or detached families of mixed-blood stock of the same Powhatan origin, numbering altogether possibly I 20 souls. What seems to be the largest of these, according to Pamunkey information, resides on Mattapony river, about Aylett postoffice, in upper King William county, the principal family names being Adams and Holmes. They are said to number about 40 in all, and to be in very backward condition as compared with the Pamunkey, with whom they have little communication, although sometimes visiting the Mattapony.

Another band of nearly the same number is situated south of Rappahannock river, about Lloyd or Battery postoffice, in upper Essex county, the most common family name being Nelson. They are said to show as much of Indian blood as the Pamunkey, holding themselves apart from both white and negro, and are represented as fairly prosperous and intelligent. They are probably the descendants of the old Nantaughtacund tribe, known later, with others, under the name of Portobacco.

Another small group is reported on the head of Pocoson river, York county, northwest from Hampton, the principal family name being Wise. 
On the north side of York river, at Gloucester Point, Gloucester county, are the descendants of a family of Sampsons, whose ancestors came originally from the Pamunkey reservation.

On the Eastern shore there are said to be a very few mixedbloods still living in the neighborhood of Accomac Courthouse (Drummondtown), in Accomac county; and also a few bearing the family name of Miles near Fisher's Inlet, in southern Northampton county.

BuREAC OF AMERICAN ETHNOLOGY, WASHINGTON, D. C: 